\title{
INCIDENCE, MORTALITY, AND SEX DISTRIBUTION OF MONGOLOID DEFECTIVES
}

\author{
BY \\ R. G. RECORD AND ALWYN SMITH \\ From the Department of Social Medicine, University of Birmingham
}

The incidence of mongolism has been expressed in various ways. It was estimated among inmates of mental deficiency institutions by Shuttleworth (1909) and several of his contemporaries. Other workers, such as Bleyer (1932), calculated its incidence in patients attending paediatric clinics. Attempts have also been made to relate the number of living mongòls to the total population (Doxiades and Portius, 1938; Böök and Reed, 1950). Since the mortality of mongols in infancy is probably high (Øster, 1953), such estimates are of limited value. Perhaps the most satisfactory data yet available are those derived from maternity hospitals. Øster (1953) collected from the literature eight hospital series which gave frequencies ranging from 0.5 to 3.4 per 1,000 births, but rejected the highest (Beidleman, 1945) and the lowest (Stevenson, Worcester, and Rice, 1950), which showed a remarkable discrepancy considering that they were derived from the same hospital. The incidence in the six remaining hospitals ranged from $1 \cdot 1$ to $2 \cdot 1$ (mean $1 \cdot 7$ ) per 1,000 births. To these may be added Øster's estimate of 0.84 , and that of Carter and MacCarthy (1951) of $1 \cdot 5$ per 1,000 . The last authors obtained their data from several hospitals, and noted that incidence was above average $(2 \cdot 1$ and $1 \cdot 6$ per 1,000 ) in two hospitals where the staff were particularly interested in mongolism.

Cases selected from maternity hospitals may not, however, be sufficiently representative for investigation of mortality, or of certain aetiological features such as fertility. Unfortunately the difficulties in obtaining more satisfactory series are considerable. Ascertainment is incomplete among hospital births, and must be even less complete among domiciliary births, where the standard of diagnosis is inevitably lower. It is probable that many cases die unrecognized in early infancy; even if diagnosed, death may be ascribed to a more immediate cause and mention of mongolism may be omitted from the death certificate.
In view of these difficulties, a series derived from all births in a large community is almost certain to be incomplete and may not be free from bias. We considered, however, that it might be more useful for study than a series collected solely from hospital births.

\section{MATERIAL}

An attempt was made to collect all cases of mongolism born during the eleven years 1942 to 1952 to mothers normally resident in the City of Birmingham. The series was compiled from the following sources:

(a) Records of five maternity hospitals and three maternity units of general hospitals.

(b) Records of the Children's Hospital and the paediatric wards and out-patient records of other hospitals.

(c) Register of infant deaths maintained by the Maternity and Child Welfare section of the Public Health Department.

(d) Records of the Mental Health section of the Local Authority.

(e) A series of cases of congenital heart disease previously assembled (MacMahon, McKeown, and Record, 1953).

The total number of related births was ascertained from the Registrar General's Statistical Reviews for each of the eleven years under consideration. The number of hospital births was derived from records of the Maternity and Child Welfare Section of the City's Public Health Department. The total number of cases of mongolism recorded was 256, but four infants were later discovered to be unaffected, and were removed from the series. Information on survival was obtained by interrogation of the mother who was visited in her home. In 217 cases, the mothers were traced and co-operated in the investigation. Of the remainder, 32 had moved to unknown addresses, and three refused information.

\section{RESULTS}

During the period, 252 mongols were identified in a population of 231,619 total births (1.09 per 1,000). The incidence of mongolism at birth has not previously been given for a large general 
population, but from knowledge of incidence in maternity hospitals, and by correcting for differences in maternal age distribution, Carter and MacCarthy (1951) estimated the incidence in England and Wales as at least 1.60 per 1,000 maternities (equivalent to 1.58 per 1,000 births). It seems likely, therefore, that ascertainment in the present series is incomplete. In seeking an explanation of the deficiency we have divided the series according to place of birth (Table I). The observed incidence of mongolism is greater among infants born in hospitals than among domiciliary and nursing home births, although the domiciliary group, with a greater proportion of older mothers, would be expected to give a higher incidence than the hospital series.

TABLe I

INCIDENCE OF MONGOLISM AMONG BIRMINGHAM BIRTHS, 1942-52

\begin{tabular}{cc|c|c|c}
\hline \multicolumn{1}{c|}{ Place of Birth } & No. of Cases & $\begin{array}{c}\text { Total Related } \\
\text { Births (live } \\
\text { and still) }\end{array}$ & $\begin{array}{c}\text { Incidence per } \\
\text { 1,000 Total } \\
\text { Births }\end{array}$ \\
\hline $\begin{array}{l}\text { Hospital } \\
\text { Home and } \\
\text { Home Nursing- }\end{array}$ & $\cdots$ & 120 & 99,228 & $1 \cdot 21$ \\
\hline Total & $\cdots$ & 132 & 132,391 & $1 \cdot 00$ \\
\hline
\end{tabular}

Even among hospital-born children ascertainment appears to be incomplete. Incidences in the eight hospitals (Table II) show considerable variation (from 0.70 to 1.91 per 1,000 births).

Incomplete ascertainment would be less serious if cases could be regarded as being representative. Unfortunately the manner in which the series was assembled precludes any guarantee of randomness in so far as mortality is concerned. This is demonstrated in Table III, in which mortality rates of cases born in the three hospitals (A, E, and F) which recorded the highest incidence are compared with those of the remainder of the series. The comparison
TABLE II

INCIDENCE AMONG BIRMINGHAM HOSPITAL BIRTHS, 1942-52

\begin{tabular}{c|c|c|c}
\hline Hospital & $\begin{array}{c}\text { No. of } \\
\text { Affected }\end{array}$ & $\begin{array}{c}\text { Total Related } \\
\text { Births (live } \\
\text { and still) }\end{array}$ & $\begin{array}{c}\text { Incidence } \\
\text { per 1,000 } \\
\text { Total Births }\end{array}$ \\
\hline A & 17 & 8,911 & $1 \cdot 91$ \\
B & 12 & 9,175 & $1 \cdot 31$ \\
C & 11 & 9,865 & $1 \cdot 12$ \\
D & 24 & 17,779 & $1 \cdot 35$ \\
E & 20 & 11,575 & $1 \cdot 73$ \\
F & 10 & 6,851 & $1 \cdot 46$ \\
G & 4 & 3,643 & $1 \cdot 10$ \\
H & 22 & 31,429 & $0 \cdot 70$ \\
\hline Total .. & 120 & 99,228 & $1 \cdot 21$ \\
\hline
\end{tabular}

is of course restricted to cases whose mothers were interviewed, since the fate of untraced cases was not known except for a few who had died; inclusion of these would have exaggerated the mortality rates. Individuals were assumed to have been at risk for half the age period in which they were at the time of interview. Their contribution to the "number at risk" was, therefore, only half that of an individual whose fate was known at the end of the period. Statistical treatment of the stillbirths required some consideration. It is, of course, unusual to extend a Life Table back to the period before birth, but there have been so few references to the possibility of mongols being born dead that it was considered desirable to focus attention on this point. We have therefore commenced the Life Table with the period "shortly before or during birth"; the precise extent of this period is immaterial.

Cases born in the three hospitals with the highest incidences (Group 1) show a considerable stillbirth rate, a very high neonatal death rate (especially in the first week), and thereafter a mortality rate very much greater than that for the general population of comparable age. The remainder of the series (Group 2) shows a much lower neonatal death rate than Group 1. The subsequent mortality up to age 5

TABLE III

MORTALITY RATES

\begin{tabular}{|c|c|c|c|c|c|c|c|c|c|c|c|c|}
\hline \multirow{2}{*}{$\begin{array}{l}\text { Group } \quad . \\
\text { Age Period }\end{array}$} & \multirow{2}{*}{$\cdots$} & \multicolumn{5}{|c|}{ (1) Cases born in Hospitals A, E, and F } & \multicolumn{5}{|c|}{ (2) Cases born Elsewhere } & \multirow[b]{2}{*}{$\begin{array}{c}\text { Mortality } \\
\text { Rate of } \\
\text { Whole } \\
\text { Series } \\
\text { (per cent.) }\end{array}$} \\
\hline & & $\begin{array}{l}\text { No. Alive } \\
\text { at } \\
\text { Beginning } \\
\text { of Period } \\
(a)\end{array}$ & $\begin{array}{l}\text { No. of } \\
\text { Known } \\
\text { Fate at } \\
\text { End of } \\
\text { Period } \\
\quad(b)\end{array}$ & $\left(\begin{array}{c}\text { Mean } \\
\text { No. } \\
\text { at Risk } \\
\left(c=\frac{a+b}{2}\right)\end{array}\right)$ & $\begin{array}{l}\text { No. } \\
\text { Dying } \\
\text { during } \\
\text { Period } \\
\text { (d) }\end{array}$ & $\begin{array}{c}\text { Mortality } \\
\text { Rate } \\
\left(\frac{d}{c} \times 100\right)\end{array}$ & $\begin{array}{l}\text { No. Alive } \\
\text { at } \\
\text { Beginning } \\
\text { of Period } \\
(a)\end{array}$ & $\begin{array}{l}\text { No. of } \\
\text { Known } \\
\text { Fate at } \\
\text { End of } \\
\text { Period } \\
(\text { b })\end{array}$ & $\begin{array}{c}\text { Mean } \\
\text { No. } \\
\text { at Risk } \\
\left(c=\frac{a+b}{2}\right)\end{array}$ & $\begin{array}{l}\text { No. } \\
\text { Dying } \\
\text { during } \\
\text { Period } \\
\text { (d) }\end{array}$ & $\begin{array}{c}\text { Mortality } \\
\text { Rate } \\
\left(\frac{d}{c} \times 100\right)\end{array}$ & \\
\hline $\begin{array}{l}\text { Shortly before } \\
\text { during Birth } \\
\text {-1 week } . . \\
-1 \text { month } \\
-1 \text { year } . . \\
-2 \text { years } . \\
-3 \text { years } . \\
-4 \text { years } . \\
\text {-5 years } .\end{array}$ & $\begin{array}{l}\text { or } \\
\cdots \\
\cdots \\
\cdots \\
\cdots \\
\cdots \\
\cdots\end{array}$ & $\begin{array}{r}35 \\
32 \\
25 \\
22 \\
18 \\
12 \\
9 \\
6\end{array}$ & $\begin{array}{r}35 \\
32 \\
25 \\
22 \\
14 \\
10 \\
6 \\
2\end{array}$ & $\begin{array}{c}35 \\
32 \\
25 \\
22 \\
16 \\
11 \\
7 \cdot 5 \\
4\end{array}$ & $\begin{array}{l}3 \\
7 \\
3 \\
4 \\
2 \\
1 \\
0 \\
0\end{array}$ & $\begin{array}{r}8 \cdot 57 \\
21 \cdot 87 \\
12 \cdot 00 \\
18 \cdot 18 \\
12 \cdot 50 \\
9 \cdot 09 \\
-\end{array}$ & $\begin{array}{r}182 \\
181 \\
168 \\
157 \\
110 \\
101 \\
89 \\
84\end{array}$ & $\begin{array}{r}182 \\
181 \\
168 \\
155 \\
105 \\
92 \\
85 \\
76\end{array}$ & $\begin{array}{c}182 \\
181 \\
168 \\
156 \\
107 \cdot 5 \\
96 \cdot 5 \\
87 \\
80\end{array}$ & $\begin{array}{r}1 \\
13 \\
11 \\
45 \\
4 \\
3 \\
1 \\
2\end{array}$ & $\begin{array}{r}0 \cdot 55 \\
7 \cdot 18 \\
6 \cdot 55 \\
28 \cdot 85 \\
3 \cdot 72 \\
3 \cdot 11 \\
1 \cdot 15 \\
2 \cdot 50\end{array}$ & $\begin{array}{r}1 \cdot 84 \\
9 \cdot 39 \\
7 \cdot 25 \\
27 \cdot 53 \\
4 \cdot 86 \\
3 \cdot 72 \\
1 \cdot 06 \\
\mathbf{2} \cdot \mathbf{3 8}\end{array}$ \\
\hline
\end{tabular}


differs in detail from that of Group 1, but if survival for the whole period of 1 month to 5 years is calculated by the Life Table method, similar results are obtained for the two groups. The chance of an infant alive at 1 month surviving to 5 years is 0.651 for Group 1 and 0.635 for Group 2 .

The incidence of mongols in the three hospitals comprising Group 1 ( $1 \cdot 72$ per 1,000 total births) is high enough to suggest that ascertainment is reasonably complete. We consider, therefore, that in spite of the small numbers of this group and the possibility that it may not be perfectly representative, it provides a more realiable estimate of neonatal mortality than the whole series, in which ascertainment of neonatal deaths is almost certainly deficient. The agreement between Groups 1 and 2 in survival rate after the first month suggests that they may be combined in assessing later mortality.

Survival rates based on the experience of Group 1 until the age of 1 month and thereafter on the whole series are given in Table IV. It is estimated that nearly two-fifths of mongols alive shortly before birth were dead by the end of the first month, less than half survived the first year, and only about two-fifths were still alive at 5 years. The survival rate at 1 year ( 45.6 per cent.) agrees well with an estimate made by Øster (1953) based on 72 hospitalborn mongols, of whom 47 per cent. were alive at 1 year.

\section{TABLE IV}

ESTIMATED SURVIVAL RATES

(Based on figures in bold type in Table III)

\begin{tabular}{|c|c|c|c|c|c|c|}
\hline \multicolumn{6}{|c|}{ Age } & Number Alive \\
\hline $\begin{array}{l}\text { Shortly b } \\
\text { Birth } \\
1 \text { week } \\
1 \text { month } \\
1 \text { year } \\
2 \text { years } \\
3 \text { years } \\
4 \text { years } \\
5 \text { years }\end{array}$ & $\begin{array}{c}\text { fore } \\
\ldots \\
\ldots \\
\ldots \\
\ldots \\
\ldots \\
\ldots \\
\ldots\end{array}$ & $\begin{array}{c}\text { rth } \\
\ldots \\
\ldots \\
\ldots \\
\ldots \\
\ldots \\
\ldots \\
\ldots\end{array}$ & $\begin{array}{l}\ldots \\
\cdots \\
\cdots \\
\cdots \\
\cdots \\
\cdots \\
\cdots\end{array}$ & $\begin{array}{l}\ldots \\
\ldots \\
\ldots \\
\ldots \\
\ldots \\
\ldots \\
\ldots \\
\ldots\end{array}$ & $\begin{array}{l}\ldots \\
\ldots \\
\ldots \\
\ldots \\
\cdots \\
\ldots \\
\ldots\end{array}$ & $\begin{array}{r}1,000 \\
914 \\
714 \\
629 \\
456 \\
433 \\
417 \\
413 \\
403\end{array}$ \\
\hline
\end{tabular}

There appears to be an interesting difference between males and females in respect of survival. The number of cases in Group 1 is too small to permit examination of mortality for each sex, and in what follows we have combined Groups 1 and 2. Mortality rates for males and females calculated by the method illustrated in Table III are given in Table V. These rates have been used to estimate the probable number of survivors at each age, and the percentage of males among the survivors has been calculated (Table VI). For most of the age periods studied, the mortality rates are higher for females than for males, and the sex-ratio (percentage of males) of survivors therefore shows a fairly steady rise with age.

TABLE V

MORTALITY RATES FOR MALES AND FEMALES

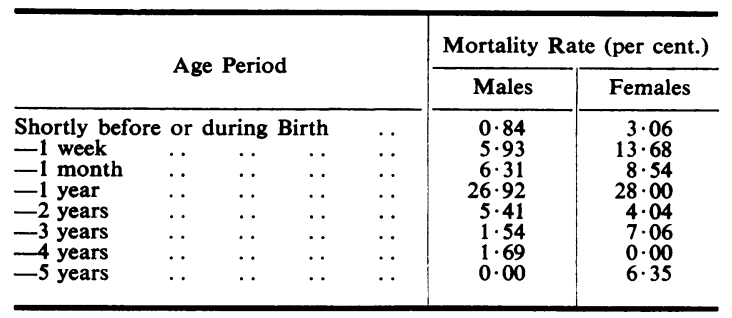

TABLE VI

ESTIMATE OF SURVIVAL OF MALES AND FEMALES

\begin{tabular}{|c|c|c|c|c|c|}
\hline \multicolumn{3}{|c|}{ Age } & $\begin{array}{l}\text { No. of } \\
\text { Males } \\
\text { Alive }\end{array}$ & $\begin{array}{l}\text { No. of } \\
\text { Females } \\
\text { Alive }\end{array}$ & $\begin{array}{c}\text { Sex-ratio of } \\
\text { Living Mongols } \\
\text { (per cent. male) }\end{array}$ \\
\hline $\begin{array}{l}\text { Shortly be } \\
\text { Birth } \\
1 \text { week } \\
1 \text { month } \\
1 \text { year } \\
2 \text { years } \\
3 \text { years } \\
4 \text { years } \\
5 \text { years }\end{array}$ & $\begin{array}{c}\text { efor } \\
\ldots \\
\ldots \\
\ldots \\
\ldots \\
\ldots \\
\ldots \\
\ldots\end{array}$ & $\begin{array}{c}\text { irth } \\
\ldots \\
\ldots \\
\ldots \\
\ldots \\
\ldots \\
\ldots \\
\ldots\end{array}$ & $\begin{array}{r}119 \cdot 0 \\
118 \cdot 0 \\
111 \cdot 0 \\
104 \cdot 0 \\
76 \cdot 0 \\
71 \cdot 9 \\
70 \cdot 8 \\
69 \cdot 6 \\
69 \cdot 6\end{array}$ & $\begin{array}{l}98 \cdot 0 \\
95 \cdot 0 \\
82 \cdot 0 \\
75 \cdot 0 \\
54 \cdot 0 \\
51 \cdot 8 \\
48 \cdot 2 \\
48 \cdot 2 \\
45 \cdot 1\end{array}$ & $\begin{array}{l}54 \cdot 8 \\
55 \cdot 4 \\
57 \cdot 5 \\
58 \cdot 1 \\
58 \cdot 5 \\
58 \cdot 1 \\
59 \cdot 5 \\
59 \cdot 1 \\
60 \cdot 7\end{array}$ \\
\hline
\end{tabular}

Before accepting this result we should inquire whether it may be explained by the method by which the series was assembled. For example, if parents were more agreeable to certification of the defective when the child was a boy, the sex-ratio of individuals alive from the age of 2 years (up to which time certification is rare) would obviously be greater than the sex-ratio at birth. But this explanation would not account for the steady rise in sex-ratio from "before birth" to the end of the first year. We conclude that among mongoloid defectives the mortality rate in infancy and early childhood is greater for females than for males. Penrose (1932) came to the same conclusion, but Hug (1951) rejected this view and demonstrated in his series of 130 mongols a higher mortality in males. Øster (1953) did not comment on this point, but his data on 460 mongols show that 59 per cent. of males and 67 per cent. of females had died at the time of follow-up.

In the whole series of 252 mongols, the number of known deaths was 116. In most cases the immediate cause of death was not certified. From the limited information available (Table VII, opposite), it would appear that death is most commonly ascribed to infections, especially of the respiratory tract, and to congenital malformations. The seasonal distribution of deaths (Table VIII, opposite) reflects the high incidence of respiratory infections. 
TABLE VII

CERTIFIED CAUSE OF DEATH

\begin{tabular}{|c|c|c|c|c|c|}
\hline Cause & $\begin{array}{c}\text { Still } \\
\text { Births }\end{array}$ & $\begin{array}{c}\text { Neonatal } \\
\text { Deaths }\end{array}$ & $\begin{array}{c}\text { Later } \\
\text { Infant } \\
\text { Deaths }\end{array}$ & $\begin{array}{c}\text { Deaths } \\
\text { after } \\
\text { First } \\
\text { Year }\end{array}$ & Total \\
\hline 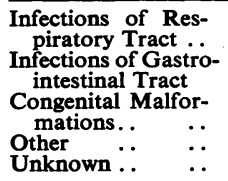 & $\begin{array}{l}- \\
\frac{-}{4}\end{array}$ & $\begin{array}{c}2 \\
2 \\
\frac{10^{*}}{26}\end{array}$ & $\begin{array}{c}16 \\
6 \\
4 \dagger \\
2 \ddagger \\
26\end{array}$ & $\begin{array}{c}5 \\
- \\
1 \\
4 \S \\
8\end{array}$ & $\begin{array}{r}23 \\
8 \\
15 \\
6 \\
64\end{array}$ \\
\hline Total & 4 & 40 & 54 & 18 & 116 \\
\hline
\end{tabular}

* Congenital heart disease, 5 ; meningocoele, 1 ; duodenal stenosis, 1 ; sclerema neonatorum, 1; multiple malformations, 2.

t Congenital heart disease, 3; hydronephrosis, 1.

$\$$ Meningitis, 1 ; suffocation, 1 .

$\$$ Scarlet fever, 1 ; acute dilatation of the stomach, 1 ; sinus thrombosis, 1 ; suffocation, 1 .

TABLE VIII

SEASONAL DISTRIBUTION* OF DEATHS

\begin{tabular}{|c|c|c|c|c|c|}
\hline Month of Death & $\begin{array}{c}\text { Still } \\
\text { Births }\end{array}$ & $\begin{array}{l}\text { Neonatal } \\
\text { Deaths }\end{array}$ & $\begin{array}{l}\text { Later } \\
\text { Infant } \\
\text { Deaths }\end{array}$ & $\begin{array}{l}\text { Deaths } \\
\text { after } \\
\text { First } \\
\text { Year }\end{array}$ & Total \\
\hline $\begin{array}{ll}\text { January-March } & \ldots \\
\text { April-June } & \ldots \\
\text { July-September } & \ldots \\
\text { October-December }\end{array}$ & $\begin{array}{l}\overline{1} \\
1 \\
2\end{array}$ & $\begin{array}{r}11 \\
11 \\
9 \\
9\end{array}$ & $\begin{array}{r}23 \\
9 \\
11 \\
11\end{array}$ & $\begin{array}{l}5 \\
3 \\
4 \\
4\end{array}$ & $\begin{array}{l}39 \\
24 \\
25 \\
26\end{array}$ \\
\hline Total & 4 & 40 & 54 & 16 & 114 \\
\hline
\end{tabular}

* Season unknown in two cases.

\section{Discussion}

The results of this investigation indicate a considerable mortality among mongols in infancy. It follows that a series identified at an early age is likely to show a higher incidence than one in which diagnosis has been delayed. If, as our results suggest, female mongols experience a greater mortality rate than males, we should expect an inverse correlation between the recorded incidence of the condition in a series and the sex-ratio (expressed as the percentage of males) of its members.

Examination of our series according to place of birth supports this view, the sex-ratio being 48.9 per cent. for the three maternity units with a high incidence, 56.2 per cent. for the other hospitals, and 56.8 per cent. for domiciliary and nursing-home births (Table IX). Many of the cases in the last two groups were not, of course, diagnosed until a considerable time after birth, but even when a series is confined to individuals diagnosed in a maternity hospital the same inverse relationship between sex-ratio and incidence may be present. This may be demonstrated in a series published by Øster (1953); the numbers are small, but this disadvantage may be offset to some extent by the fact that the cases may be divided in two ways-according to place of birth and according to year of birth (Table X).

TABLE IX

INCIDENCE AND SEX-RATIO ACCORDING TO PLACE OF, BIRTH

(Birmingham, 1942-52)

\begin{tabular}{|c|c|c|c|c|c|c|}
\hline $\begin{array}{c}\text { Place of } \\
\text { Birth }\end{array}$ & Males & $\begin{array}{c}\text { Fe- } \\
\text { males }\end{array}$ & Total & $\begin{array}{c}\text { Related } \\
\text { Births }\end{array}$ & $\begin{array}{c}\text { Sex-ratio } \\
\text { (per cent. } \\
\text { male) }\end{array}$ & $\begin{array}{c}\text { Incidence } \\
\text { (per 1,000 } \\
\text { births) }\end{array}$ \\
\hline $\begin{array}{r}\text { Hospitals } \\
\text { A, E, and } \\
\text { F } . \\
\text { Other Hos- } \\
\text { pitals } . \\
\text { Home or } \\
\text { Nursing- } \\
\text { home... }\end{array}$ & $\begin{array}{l}41 \\
75\end{array}$ & 32 & 73 & $\begin{array}{c}\cdot \\
27,337 \\
71,891 \\
132,391\end{array}$ & $\begin{array}{r}48 \cdot 9 \\
56 \cdot 2 \\
56 \cdot 8\end{array}$ & $\begin{array}{l}1 \cdot 72 \\
1.02 \\
1.00\end{array}$ \\
\hline Total .. & 139 & 113 & 252 & 231,619 & $55 \cdot 2$ & 1.09 \\
\hline
\end{tabular}

TABLE $X$

INCIDENCE AND SEX-RATIO OF CASES BORN IN RIGSHOSPITALET, DENMARK

(Derived from data published by Øster, 1953)

\begin{tabular}{|c|c|c|c|c|c|c|c|}
\hline Period & $\begin{array}{l}\text { De- } \\
\text { part- } \\
\text { ment }\end{array}$ & Males & $\begin{array}{c}\text { Fe- } \\
\text { males }\end{array}$ & Total & $\begin{array}{c}\text { Related } \\
\text { Births }\end{array}$ & $\begin{array}{c}\text { Sex-ratio } \\
\text { (per cent. } \\
\text { male) }\end{array}$ & $\begin{array}{c}\text { Inci- } \\
\text { dence } \\
\text { (per } \\
1,000 \\
\text { Births) }\end{array}$ \\
\hline $923-48$ & $\begin{array}{l}\mathbf{A} \\
\mathbf{B}\end{array}$ & $\begin{array}{l}17 \\
22\end{array}$ & $\begin{array}{l}12 \\
20\end{array}$ & $\begin{array}{l}29 \\
42\end{array}$ & & & $\begin{array}{l}0.71 \\
0.98\end{array}$ \\
\hline $\begin{array}{l}1923-37 \\
1938-48\end{array}$ & Both & $\begin{array}{l}12 \\
27\end{array}$ & $\begin{array}{r}7 \\
25\end{array}$ & $\begin{array}{l}19 \\
52\end{array}$ & $\begin{array}{l}44,284 \\
39,788\end{array}$ & $\begin{array}{l}63 \cdot 2 \\
51 \cdot 9\end{array}$ & $\begin{array}{l}0.43 \\
1.31\end{array}$ \\
\hline
\end{tabular}

It follows from the foregoing that a series collected from mental deficiency institutions may be expected to show a high sex-ratio. Hug (1951) fully demonstrated this point $(63.3$ per cent. males in 982 institutional cases collected from the literature) and considered that it could not be explained by preferential selection of males for admission into institutions. Our evidence supports the view that the relatively low survival rate of females may account for this high sex-ratio, but Hug, having shown in his collection of 130 mongols a higher mortality rate in males, did not accept this explanation. He considered that the primary sex-ratio in mongolism is high and that the observed higher incidence in males cannot be explained by differences in mortality. In an attempt to support this view, he assembled data from ten publications which give maternal age and sex of mongols. He showed a falling sex-ratio with rising maternal age $(63.5$ per cent. male for mothers under $30,61 \cdot 1$ per cent. for those aged 30-39, and 55.0 per cent. for those of 40 and over). From the analogy between these figures and those for all live births, he concluded that the pre-natal mortality rates of mongols increase with 
maternal age and are higher for males than for females. But since few of the cases in this collection were ascertained at birth, the falling sex-ratio by maternal age does not necessarily reflect the influence of the intra-uterine environment. To test this point we have added our own cases from the three hospitals with high incidence to the two series from the literature in which it is reasonably certain that cases were diagnosed at or soon after birth and which gave sex and maternal age. The combined material (Table XI) fails to show the trend in sex-ratio by maternal age obtained by Hug.

TABLE XI

SEX RATIO ACCORDING TO MATERNAL AGE OF CASES DIAGNOSED AT BIRTH

\begin{tabular}{|c|c|c|c|c|c|c|}
\hline \multirow{3}{*}{ Series } & \multicolumn{6}{|c|}{ Maternal Age (yrs) } \\
\hline & \multicolumn{2}{|c|}{ Under 30} & \multicolumn{2}{|c|}{$30-39$} & \multicolumn{2}{|c|}{$\begin{array}{l}40 \text { and } \\
\text { Over }\end{array}$} \\
\hline & $\mathbf{M}$ & $\mathbf{F}$ & $\mathbf{M}$ & $\mathbf{F}$ & $\mathbf{M}$ & $\mathbf{F}$ \\
\hline $\begin{array}{lll}\text { Hug }(1951) & \ldots & \ldots \\
\text { Beidleman (1945) } & \cdots & \cdots \\
\text { Present series } & \\
& (\text { Hospitals A, E, and F) }\end{array}$ & $\begin{array}{r}16 \\
4 \\
1\end{array}$ & $\begin{array}{r}10 \\
10 \\
7\end{array}$ & $\begin{array}{r}42 \\
7 \\
5\end{array}$ & $\begin{array}{r}19 \\
9\end{array}$ & $\begin{array}{r}27 \\
4\end{array}$ & $\begin{array}{r}16 \\
8\end{array}$ \\
\hline Total & 21 & 27 & 54 & 38 & 40 & 27 \\
\hline Sex-ratio (per cent. males). . & \multicolumn{2}{|c|}{$43 \cdot 8$} & \multicolumn{2}{|c|}{$58 \cdot 7$} & \multicolumn{2}{|c|}{$59 \cdot 7$} \\
\hline
\end{tabular}

Further suggestive evidence may be advanced against Hug's hypothesis. Table XII has been prepared from data published by Penrose (1934), the most extensive material on maternal age, birth rank, and sex of mongols available in. the literature. Although a fairly coarse grouping has been used, numbers in some cells are inevitably small. Nevertheless there is a fairly regular rise in sex-ratio with birth rank and a fall with maternal age. The sex-ratio of all live births shows a very different pattern; it falls with birth rank if maternal age is fixed and shows no association with maternal age if birth rank is fixed (MacMahon and Pugh, 1953).

TABLE XII

SEX-RATIO* ACCORDING TO MATERNAL AGE AND BIRTH RANK

(From data recorded by Penrose, 1934)

\begin{tabular}{|c|c|c|c|c|c|}
\hline \multirow{2}{*}{\multicolumn{3}{|c|}{ Birth Rank }} & \multicolumn{3}{|c|}{ Maternal Age (yrs) } \\
\hline & & & \multirow{2}{*}{$\begin{array}{c}\text { Under } 30 \\
\begin{array}{c}54 \\
(26)\end{array}\end{array}$} & \multirow{2}{*}{ 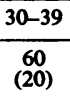 } & \multirow{2}{*}{$\begin{array}{c}40 \text { and Over } \\
43 \\
(7)\end{array}$} \\
\hline 1 and $2 \ldots$ & . & . & & & \\
\hline 3 and $4 \ldots$ & . & . & $\begin{array}{r}100 \\
(3)\end{array}$ & $\begin{array}{c}64 \\
(30)\end{array}$ & $\begin{array}{c}50 \\
(18)\end{array}$ \\
\hline 5 and Over & . & .. & $\overrightarrow{(1)}$ & $\begin{array}{c}73 \\
(41)\end{array}$ & $\begin{array}{c}63 \\
\text { (78) }\end{array}$ \\
\hline
\end{tabular}

* Expressed as percentage of males.

Number of cases is given in brackets.
Hug's observation of a falling sex-ratio of mongols with advancing maternal age cannot, therefore, be explained by differential intra-uterine mortality. We consider that it is more likely to result from the influence of the post-natal environment. Support for this view is provided by a comparison of Penrose's material (Table XII) with infant mortality rates in Birmingham in 1947, calculated by Gibson and McKeown (1952), here repeated in abridged form (Table XIII). Groupings both of maternal age and

TABLE XIII

INFANT MORTALITY RATES* IN BIRMINGHAM, 1947, ACCORDING TO MATERNAL AGE AND BIRTH RANK (Gibson and McKeown, 1952)

\begin{tabular}{|c|c|c|c|c|c|c|}
\hline \multirow{2}{*}{\multicolumn{4}{|c|}{ Birth Rank }} & \multicolumn{3}{|c|}{ Maternal Age (yrs) } \\
\hline & & & & \multirow{2}{*}{$\frac{\text { Under } 25}{31 \cdot 3}$} & \multirow{2}{*}{$\frac{25-29}{16 \cdot 9}$} & \multirow{2}{*}{$\frac{30 \text { and Over }}{37 \cdot 4}$} \\
\hline $1 \ldots$ & . & . & $\ldots$ & & & \\
\hline 2. & $\ldots$ & $\ldots$ & . & $47 \cdot 4$ & $34 \cdot 0$ & $25 \cdot 7$ \\
\hline 3.. & $\cdots$ & . & . & $76 \cdot 1$ & $44 \cdot 1$ & $25 \cdot 2$ \\
\hline 4 an & Over & $\ldots$ & .. & $98 \cdot 2$ & $59 \cdot 2$ & $45 \cdot 7$ \\
\hline
\end{tabular}

* Expressed as number of deaths per 1,000 live births.

of birth rank are not the same, but, whether the two Tables are compared vertically or horizontally, they show a close correspondence between the sex-ratio of mongols and the rate of infant mortality in the general population. Gibson and McKeown showed that deaths from infection accounted for nearly all the association between infant mortality and birth rank and maternal age. It is well recognized (and shown in our series-Table VII) that mongols are peculiarly susceptible to infection.

Analysis of our data fails to show any consistent trend in sex-ratio either by maternal age or by birth rank. This is hardly surprising in view of the fact that our cases were, in general, diagnosed at a much earlier age than those in Penrose's series, and had, therefore been less influenced by the post-natal environment at the time of ascertainment.

We consider that these observations support the view that among mongols in an adverse environment females are more likely to die in early life than males, and that in order to assemble a representative series diagnosis early in the neonatal period is essential. Only some of our cases fulfil this condition, and it is probable that the whole series shows too low an incidence and too high a sex-ratio. Nevertheless it is possibly more representative than most other series which have been assembled, and we hope to publish a detailed examination of the material in a subsequent communication. 


\section{SUMMARY}

(1) 252 mongols $(1.09$ per 1,000$)$ were identified among 231,619 total births in Birmingham in the years 1942-52.

(2) It was estimated that nearly two-fifths of mongols alive shortly before birth were dead by the end of the first month, less than half survived the first year, and only about two-fifths were alive at 5 years.

(3) Females showed greater mortality rates in infancy and early childhood than males. It is suggested that this may account for the inverse relationship between sex-ratio and maternal age, and between sex-ratio and recorded incidence.

(4) Death was commonly ascribed to infections of the respiratory tract, and somewhat less frequently to congenital malformations and gastrointestinal infections. More deaths occurred in the first quarter of the year than at other seasons.
For permission to examine records we are indebted to the staffs of Birmingham hospitals and to the Birmingham Maternity and Child Welfare and Mental Health Departments. Observations were recorded in the homes of cases by Miss Mary Gradwell and Miss Eileen Gibson.

\section{REFERENCES}

Beidleman, B. (1945). Amer. J. ment. Defic., 50, 35.

Bleyer, A. (1932). Amer. J. Dis. Child., 44, 503.

Böbk, J. A., and Reed, S. C. (1950). J. Amer. med. Ass., 143, 730.

Bobk, J. A., and Reed, S. C. (1950). J. Amer. med. Ass., 143, 730. Medicine, 5,83 .

Doxiades, L., and Portius, W. (1938). Z. menschl. Vererb.- u. Konstit. Lehre 21, 384.

Gibson, J. R., and McKeown, T. (1952). British Journal of Social Medicine, 6, 183.

Hug, E. (1951). Ann. paediat. (Basel), 177, 31.

MacMahon, B., McKeown, T., and Record, R. G. (1953). Brit. Heart J., 15, 121 .

, and Pugh, T. F. (1953). British Journal of Preventive and Social Medicine, 7, 83.

Øster, J. (1953). "Mongolism. A clinicogenealogical investigation comprising 526 mongols living on Seeland and neighbouring islands in Denmark". Danish Science Press, Copenhagen.

Penrose, L. S. (1932). J. Genet., 25, 407.

Penrose, L4. S. (1932). J. Genet., 25, 407.

Shuttleworth, G. E. (1909). Brit. med. J., 2, 661.

Stevenson, S. S., Worcester, J., and Rice, R. G. (1950). Pediatrics, 